\title{
Changes in the Paneth cell population of human small intestine assessed by image analysis of the secretory granule area
}

\author{
MARGARET E ELMES, J GWYN JONES, MR STANTON \\ From the Department of Pathology, University Hospital of Wales, Heath Park, Cardiff CF4 4 XN
}

SUMMARY Estimates of the Paneth cell population in human jejunum and ileum were made using measurement of the granule area in $\mu \mathrm{m}^{2}$ by image analysis in a defined number of crypts. This figure was preferable to granule area per $\mathrm{mm}$ as there was a significant difference in crypts per $\mathrm{mm}$ between biopsies and surgical samples.

In the jejunum no significant difference was found between normal children and adults with and without peptic ulcer. In adults with subtotal or partial villous atrophy the decrease in area was not statistically significant and there was no decrease in area in children with partial villous atrophy and coeliac disease.

There was a marked increase in granule area in the jejunum of patients who had had a previous partial gastrectomy which was statistically significant.

In the ileum patients with carcinoma of the caecum had higher values than patients with non-inflammatory non-malignant conditions but this was not statistically significant and two patients with Crohn's disease had an increased granule area.

Paneth cell populations are affected by alterations in the intestinal luminal environment due to previous surgery or neoplastic or inflammatory disease.

The current techniques of estimating Paneth cell populations in sections of small intestine depend on granule staining of cells either in a measured length of mucosa, ${ }^{12}$ or by calculating the number of Paneth cells per crypt, ${ }^{34}$ or by measuring the proportion of Paneth cell containing crypts in a section. ${ }^{56}$ In addition to haematoxylin and eosin special stains such as Masson's trichrome, Lendrum's phloxine tartrazine and immunostaining for lysozyme (muramidase) and IgA have been used. ${ }^{78}$ There are many potential sources of error. The staining depends on a cell containing reactive granules and granule loss can occur during fixation if acid fixatives such as Bouin's fluid are used. ${ }^{9}$ The nature of the marker used may cause problems; phloxine tartrazine stains argentaffin cells and lysozyme is found in goblet cells and some lamina propria cells as well as Paneth cells. Any estimate of the number of cells present should take into account the average size of the cell and the fact that parts of any one cell will be present in adjacent sections. Even when all cells are accurately counted

Accepted for publication 28 March 1983 different degrees of tissue shrinkage during fixation and processing make comparisons difficult.

The aim of this work was to devise a technique of estimating Paneth cell populations in man in which both small biopsy specimens and large surgical specimens could be compared, and to minimise errors due to tissue shrinkage, subjective assessment, and difficulty in identifying Paneth cells. Image analysis was used to measure the area occupied by stained Paneth cell granules in a defined number of crypts, and changes in this area correlated with different pathological conditions.

\section{Material and methods}

Samples of jejunal and ileal mucosa were obtained from two sources-jejunal biopsy for diagnostic purposes and intestinal resection for disease.

A total of 77 specimens were examined, 56 adults age 17-83 yr (mean 56) and 21 children age 6 months -16 yr (mean 7).

The patients were divided into the following groups: 1 Biopsy samples (jejunum)

(a) Non-coeliac disease This group consisted of five adults and 13 children. The adults were being 
investigated for anaemia or malabsorption and the children for short stature or unexplained diarrhoea. All mucosal samples were histologically normal.

(b) Active coeliac disease The subjects were four adults with untreated coeliac disease and eight children with subtotal or partial villous atrophy due to untreated coeliac disease in four cases and after gluten challenge in four cases. Gluten challenge consisted of a normal diet for 6 months to $2 \mathrm{yr}$ after previous gluten withdrawal in three cases and a gluten-free diet with either added gluten or bread for three months in one case.

\section{Surgical specimens. All adults}

(a) Jejunum was obtained during anastomotic operations including partial gastrectomy for peptic ulcer $(\mathbf{n}=7)$, gastrointestinal anastomosis for recurrent peptic ulcer after previous surgery $(n=7)$ and gastric carcinoma $(n=9)$.

(b) Ileum from patients with non-inflammatory, non-malignant disease including Meckel's diverticulum, angiodysplasia, polyposis coli without malignant change and non-malignant obstruction (n = 7); ("Control"); carcinoma of right side of colon $(n=3)$; carcinoma of caecum $(n=8)$ and Crohn's disease $(n=6)$.

\section{STAINING TECHNIQUE}

All samples were fixed in formol saline and processed routinely. Paraffin sections (4-5 $\mu \mathrm{m})$ were cut and stained with haematoxylin and eosin and also with a modification of Lendrum's phloxine tartrazine omitting the nuclear stain, the procedure being as follows:

The dewaxed sections were stained for $5 \mathrm{~min}$ in $0.5 \%$ phloxine in $0.5 \% \mathrm{CaCl}_{2}$, rinsed in water and then differentiated in a saturated solution of tartrazine in Cellosolve until the Paneth cell granules stood out clearly against a yellow background. This took between 10 and $60 \mathrm{~min}$ and was controlled for each slide. When complete the slide was rinsed in Cellosolve, put in $95 \%$ ethanol and dehydrated and mounted in Canada balsam or DPX. The Paneth cell granules, enterochromaffin cell granules and erythrocytes appeared bright red against a yellow background.

Long periods of differentiation were needed for tissue from some cases of coeliac disease and Crohn's disease and in a few cases it was impossible to remove all red staining from the enterocyte cytoplasm.

ASSESMENT OF TISSUE SHRINKAGE

The number of crypts per $\mathrm{mm}$ was measured in $\mathbf{7 4}$ specimens stained with haematoxylin and eosin using an eyepiece graticule with a total scale length of $0.6 \mathrm{~mm}$ at a magnification of $\times 160$. At least two consecutive fields with a linear crypt base measurement of $1.2 \mathrm{~mm}$ were used but in larger specimens five consecutive fields with a crypt base measurement of $3 \mathrm{~mm}$ were observed and the number of crypts per $\mathrm{mm}$ calculated.

PANETH CELL GRANULE AREA MEASUREMENT Cell granule area measurements were made on 75 slides stained with phloxine tartrazine using a computer controlled quantitative image analyser. ${ }^{10}$ This instrument comprises a closed circuit television system connected via a beam splitter attachment to a microscope. The image received from the microscope is processed by the TV system and a minicomputer so that component parts of the image can be selected according to the degree of light intensity which they contain.

Microscope specimens are stained so that items of interest, when viewed on a television monitor, assume a specific degree of light intensity and can therefore be discriminated from the background.

To aid the process of discrimination a pseudocolour binary image is superimposed over those parts of the television picture which share the same values of light intensity. ${ }^{10}$ Once this has been done the selected regions can be processed by the computer to extract specific parameters relating to area, count etc. (Fig. 1).

To measure Paneth cell area the slide was examined using an objective power of $\times 40$ at a narrow bandwidth light wavelength of $546 \mathrm{~nm}$. This ensured that the Paneth cells granules appeared on the television screen as dense black objects set against a relatively light background (Fig. 2)

The image analyser was calibrated with a Zeiss stage micrometer so that an area of $100 \mu \mathrm{m}^{2}$ at the microscope specimen plane was equivalent to a television picture area of $134 \times 134$ picture points (pixels).

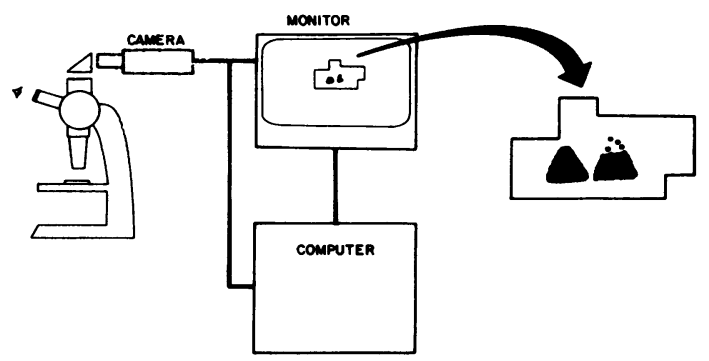

Fig. 1 Diagram of Image Analyser showing microscope, camera, monitor and diagram of appearances of two Paneth cells on the monitor to right of figure. 


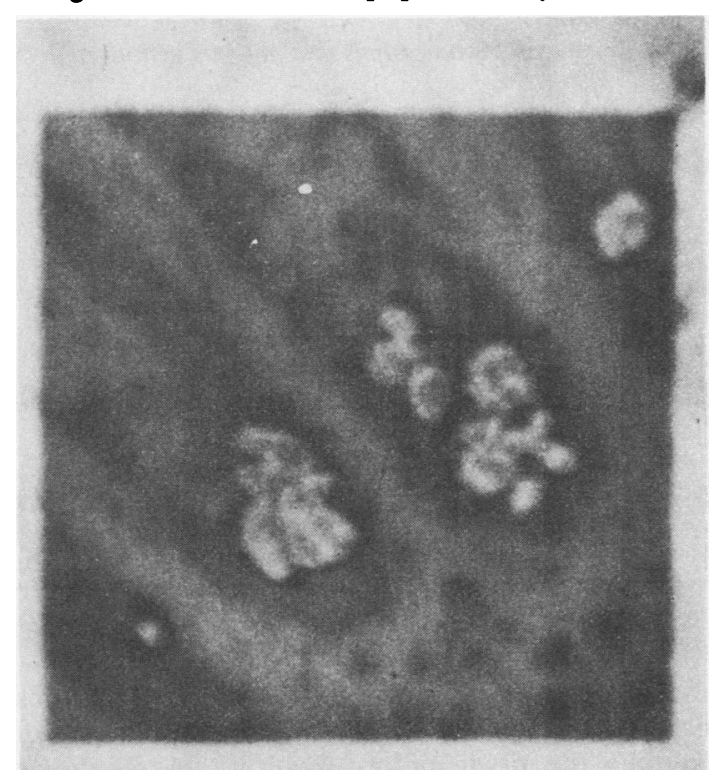

Fig. 2 Appearances of Image Analyser monitor with pseudocolour laid over Paneth cell granule area. Original slide magnification $\times 400$.

Each Paneth cell group together with a small amount of background were isolated from surrounding artefact by enclosing the granules in a variable rectangular "window" which could be positioned anywhere on the screen. Only items within the window were included in the measurements.

The black Paneth cell granules were isolated from the relatively light background by a computer programme which examined the bimodal distribution of intensity levels within the image and then selected an optimum "threshold" at which to separate one from the other.

A pseudocolour was then superimposed over the detected Paneth cell area and the numerical data relating to this area was obtained from the printer. The discrimination of the Paneth cells by the computer was successful in approximately $95 \%$ of cases. On the other occasions it was necessary to set the threshold level by hand. If artefactual regions could not be avoided and came within the measuring window, then these regions were eliminated by using a special screen light pen. ${ }^{11}$ Artefacts consisted of erythrocytes, enterochromaffin cells and persistent phloxine stain in enterocytes.

The area occupied by Paneth cell granules in a crypt was measured five times and a mean for each crypt obtained. A crypt was defined as any part of a crypt that was within $30 \mu \mathrm{m}$ of the muscularis mucosa and this included sections across the outer edge of a crypt that had no identifiable Paneth cells in them. Slides with longitudinally cut crypts were preferred but if a small badly orientated region was encountered it was ignored and the count continued in the next satisfactory area. Fifty consecutive crypts per slide were counted and if the sample was too small to have 50 crypts per slide a second slide separated by more than $5 \mu \mathrm{m}$ was used to complete the count to avoid counting the same cells twice.

By this means a Paneth cell granule area in pixels per crypt for each tissue was obtained but statistical transformation was necessary as the values obtained included many zeros and a normal distribution was obtained by using $\log _{10}(x+20)$ for each observation.The geometric mean $\frac{\log _{10}(x+20)}{50}$ was determined for each patient and all statistical analyses performed using transformed data. The final results were converted into $\mu \mathrm{m}^{2}$ by converting back into picture points (antilog ${ }_{10}-20$ ) and multiplying by the calibration factor $0.557\left(134^{2}\right.$ picture points = $100 \mu \mathrm{m}^{2}$ ).

\section{Results}

\section{ASSESSMENT OF TISSUE SHRINKAGE}

Table 1 shows the mean crypts per mm length of small intestine in the jejunum and ileum in both biopsy and surgical specimens. The group of control patients in the results from the ileum included non-malignant, non-inflammatory conditions requiring surgery such as Meckel's diverticulum, angiodysplasia of the ileum, polyposis coli and non-malignant stricture.

The overall pooled data was tested using a paired $t$ test and a significant difference $(p<0.05)$ was

Table 1 Arithmetic means and standard deviations of crypts per mm length of section

\begin{tabular}{|c|c|c|}
\hline $\begin{array}{l}\text { Jejunum } \\
\text { Surgical specimens } \\
\text { Peptic ulcer } \\
\text { Gastric carcinoma } \\
\text { Overall pooled mean }\end{array}$ & $\begin{array}{l}15.9 \pm 2.9 \\
18.7 \pm 3 \cdot 0 \\
17.2 \pm 3.2\end{array}$ & $\begin{array}{l}\mathbf{n}=\mathbf{1 0} \\
\mathbf{n}=9 \\
\mathbf{n}=\mathbf{9}\end{array}$ \\
\hline $\begin{array}{l}\text { Biopsies } \\
\text { Normal adults } \\
\text { Normal children } \\
\text { Villous atrophy, children } \\
\text { Overall pooled mean }\end{array}$ & $\begin{array}{r}13.4 \pm 2.7 \\
9.3 \pm 2.4 \\
10.0 \pm 2.7 \\
10.3 \pm 2.8\end{array}$ & $\begin{array}{l}n=5 \\
n=13 \\
n=8 \\
n=26\end{array}$ \\
\hline $\begin{array}{l}\text { Ileum } \\
\text { Surgical specimens (adult) } \\
\text { Control } \\
\text { Carcinoma colon } \\
\text { Carcinoma caecum } \\
\text { Inactive Crohn's } \\
\text { Active Crohn's } \\
\text { Overall pooled mean }\end{array}$ & $\begin{array}{l}13 \cdot 1 \pm 2.7 \\
11 \cdot 7 \pm 1 \cdot 2 \\
11 \cdot 8 \pm 2.3 \\
14.0 \pm 2.9 \\
12.5 \pm 6.4 \\
12.7 \pm 2.8\end{array}$ & $\begin{array}{l}\mathbf{n}=\mathbf{8} \\
\mathbf{n}=\mathbf{3} \\
\mathbf{n}=9 \\
\mathbf{n}=7 \\
\mathbf{n}=\mathbf{2} \\
\mathbf{n}=29\end{array}$ \\
\hline
\end{tabular}

Significant difference between surgical and biopsy specimens in jejunum ( $p<0.05)$ and between jejunal and ileal surgical specimens $(p<0.001)$ paired $t$ test. 
Table 2 Jejunal Paneth cell granule area in $\mu m^{2}$ per crypt in biopsy specimens from normals and patients with partial villous atrophy. (PVA)

\begin{tabular}{lccl}
\hline Group 1 & Group 2 & Group 3 & Group 4 \\
Normal adult & PVA adult & Normal children & PVA children \\
\hline 120.3 & 98.3 & 117.5 & 29.6 \\
51.2 & 13.9 & 36.0 & 44.6 \\
34.1 & 50.8 & 12.3 & 36.3 \\
29.0 & 111.7 & 5.6 & 46.7 \\
51.9 & & 40.9 & 31.7 \\
& & $19 \cdot 0$ & 25.0 \\
& & 40.4 & 37.3 \\
& & 43.5 & 33.8 \\
& & 49.9 & \\
Mean & 62.9 & \\
$51 \cdot 1$ & & 20.4 & \\
\hline
\end{tabular}

No statistically significant differences between groups.

found between surgical specimens and biopsies in the jejunum. Fewer crypts/mm were found in biopsy specimens, probably due to lack of a muscle coat, and therefore less shrinkage during fixation. The

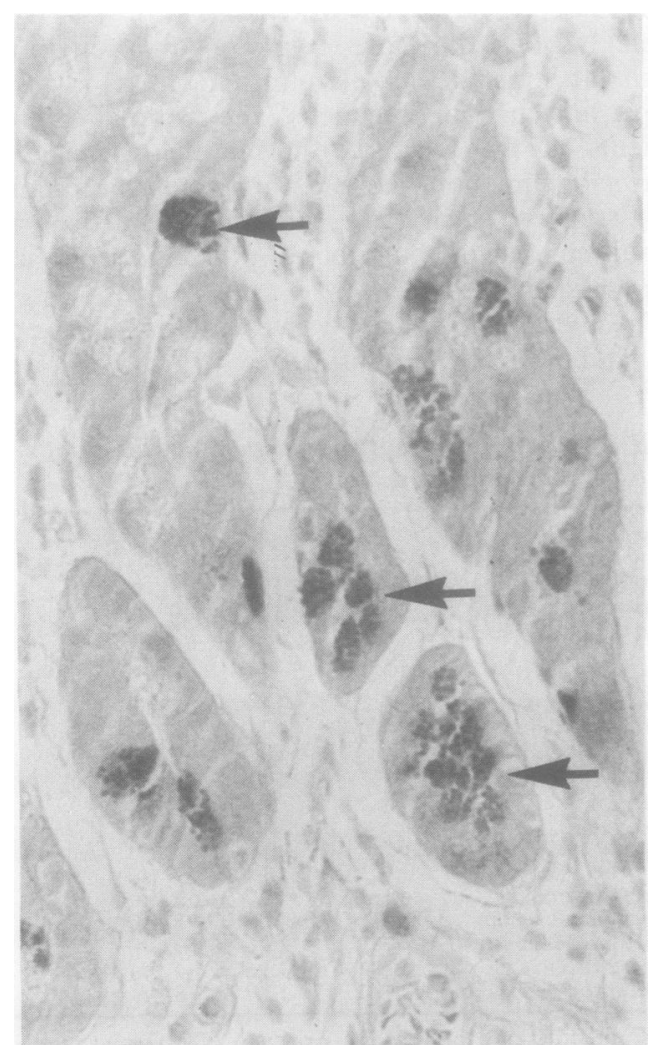

Fig. 3 Same slide as Figure 2 with Paneth cells arrowed. Post gastrectomy jejunum, phloxine tartrazine $\times \mathbf{4 0 0}$. smaller number of crypts/mm in children's biopsies may in part have been due to different techniques in handling the tissue before fixation, the children's biopsies being spread out more than the adult ones. There was no difference between children with normal biopsies and those with subtotal or partial villous atrophy.

In adults when surgical specimens from the jejunum and ileum were compared more crypts per $\mathrm{mm}$ were found in the jejunum than in the ileum ( $p$ $<0.001)$, probably anatomical variation rather than tissue shrinkage.

\section{PANETH CELL GRANULE AREA}

\section{Jejunum}

Fig. 3 shows Paneth cell granules in a post gastrectomy patient with Paneth cell increase including one high up in the crypt.

Table 2 gives the result found in biopsies from adults and children and there is no statistically significant difference between normal adults and children. The children have a lower mean value and some biopsies yielded very low counts due to apparent loss of Paneth cell granules as non-granulated cells in the correct position resembling Paneth cells were seen. This is probably due to biopsy trauma or medication as these cells were not found in surgical specimens. In a few children poorly stained Paneth cell granules were seen but the image analysis was usually sufficiently sensitive to measure granules with any tinge of red. Children with villous atrophy appeared to have fewer Paneth cells but due to the wide range of values in normal children this was not statistically significant. No child with villous atrophy had a high value in contrast to two of the normal children.

The results of both groups had a wide range of 
values. The mean value in villous atrophy was again lower than normal but did not attain statistical significance.

The remaining estimations of Paneth cell area were done on surgical specimens and in every case some pathology was present in either stomach or intestine so no group can be considered as normal.

Table 3 compares Paneth cell area in patients in group 1 (peptic ulcer, first operation), group 2 (previous partial gastrectomy requiring revision or a recurrent peptic ulcer) and group 3 (gastric carcinoma).

It is evident that the reoperated patients in group 2 had a mean Paneth cell granule area significantly higher than the other two groups $(p<0.05)$.

\section{Ileum}

As in the assessment of tissue shrinkage results the patients were classified into groups. (Table 4)

Group 1 included non-inflammatory, non-malignant conditions such as Meckel's diverticulum, angiodysplasia, polyposis coli and non-malignant stricture ("Control"). $\mathrm{n}=7$.

Group 2 Carcinoma of the caecum. $\mathbf{n}=7$.

Group 3 Crohn's disease. $\mathrm{n}=6$.

Group 1 had the lowest overall mean $\left(71.2 \mu \mathrm{m}^{2}\right)$ compared with $113.3 \mu \mathrm{m}^{2}$ in group 2 and $91.4 \mu \mathrm{m}^{2}$ in group 3, but it is apparent that there is no marked difference between groups 1 and 3. Group 2 appeared to have a considerably higher value than group 1 but on statistical analysis (paired $t$ test) the $p$ value was not significant in spite of the high levels in 4 of 8 patients. This is due to the small number of cases and one very low level. No significant increase in area over group 1 was found in the cases of Crohn's disease in group 3-the first four cases had no lesions in the portion of mucosa examined and had values comparable with group 1 . Two patients

Table 3 Jejunal Paneth cell granule area per crypt in $\mu^{2}$ in surgical specimens

\begin{tabular}{|c|c|c|}
\hline $\begin{array}{l}\text { Group } 1 \\
\text { Peptic ulcer }\end{array}$ & $\begin{array}{l}\text { Group } 2 \\
\text { Reoperated } \\
\text { peptic ulcer }\end{array}$ & $\begin{array}{l}\text { Group } 3 \\
\text { Gastric carcinoma }\end{array}$ \\
\hline $\begin{array}{l}54 \cdot 9 \\
34 \cdot 5 \\
39.8 \\
34 \cdot 8 \\
27 \cdot 6 \\
41.8 \\
60.6\end{array}$ & $\begin{array}{r}192.1 \\
95.2 \\
60.1 \\
123.0 \\
25.4 \\
48.8 \\
136.4\end{array}$ & $\begin{array}{r}76.1 \\
33.2 \\
68.3 \\
44 \cdot 3 \\
49.5 \\
16.8 \\
36.4 \\
83.9 \\
66.6 \\
115.9\end{array}$ \\
\hline $\begin{array}{l}\text { Mean } \\
40 \cdot 0\end{array}$ & $82 \cdot 2$ & 52.7 \\
\hline
\end{tabular}

A paired $t$ test on the geometric means of the above figures showed a significant difference between groups 1 and $2 ; p<0.05$.
Table 4 Ileal Paneth cell granule area per crypt in $\mu^{2}$ in surgical specimens

\begin{tabular}{lcc}
\hline $\begin{array}{l}\text { Group 1 } \\
\text { "Control" }\end{array}$ & $\begin{array}{l}\text { Group 2 } \\
\text { Carcinoma caecum }\end{array}$ & $\begin{array}{l}\text { Group } 3 \\
\text { Crohn's disease }\end{array}$ \\
\hline 83.9 & 44.4 & 92.4 \\
86.3 & 193.9 & 87.2 \\
41.4 & 148.4 & 83.9 \\
119.9 & 355.9 & 40.5 \\
79.3 & 58.5 & 152.5 \\
91.8 & 58.0 & 131.0 \\
32.6 & 158.0 & \\
& 104.8 & \\
Mean & 113.3 & 91.4 \\
71.2 & & \\
\hline
\end{tabular}

No statistically significant difference between groups.

with characteristic lesions in the mucosa examined did have high values but statistical significance was not attained.

\section{Discussion}

The choice of a quantifiable marker for any cell type is always difficult. In this case it was decided to use the acidophilic secretory granule area as an estimate of the Paneth cell population although this value can be lowered by either unstained granules, as was found in a few children, or by granule discharge. This was particularly apparent in jejunal biopsies from normal children where degranulated Paneth cells were seen resulting in low granule area values. In studies using a combined muramidase/phloxine/ tartrazine stain, (B Gormley, personal communication, 1982) the muramidase reaction product occupies a larger part of the cell than the phloxine stained granules and appears to surround the red granules. This results in an increase in the number of cells identified as Paneth cells by the muramidase technique as Scott and Brandtzaeg ${ }^{7}$ point out. In spite of this we confirmed Scott and Brandtzaeg's observation of no significant decrease in Paneth cell granule area in the jejunum in adults or children with villous atrophy.

The study on the effect of tissue preparation on crypts per $\mathrm{mm}$ demonstrates that techniques of estimating Paneth cell populations using linear measurements are more subject to error than those using a defined number of crypts. If both biopsy and surgical material is to be used the crypt counting method is essential.

In the jejunum the most marked increase was found in patients who required a second operation after a partial gastrectomy for peptic ulcer. Several of these patients had a very obvious increase in Paneth cells on microscopy with Paneth cells seen in unusual positions in the crypt (Fig. 3). It has been suggested that Paneth cells are concerned in the 
maintenance of a normal bacterial flora in the small intestine. ${ }^{12}$

Preliminary work in rats demonstrated an increase in Paneth cells in intestinal stasis due to mecamylamine or a self-emptying blind loop but a decrease in Paneth cells in self-filling blind loops and self-emptying blind loops that showed a marked increase in the bacterial flora of the lumen. ${ }^{13}$ Further work has demonstrated an increase in the Paneth cell population in the ileum of rats reared in a low bacterial environment and in isolated Thiry-Vella loops but a decrease in self-filling blind loops. ${ }^{8}$

The aim of partial gastrectomy is to reduce acidity and this combined with altered intestinal mobility predisposes to gastrointestinal bacterial overgrowth. ${ }^{14}$ We suggest that the Paneth cell proliferation observed is an attempt to prevent bacterial overgrowth in an abnormal hypochlorhydric state and individual patients who do not show this response are liable to have bacterial overgrowth in the intestinal lumen. Preliminary results in further work to be reported later support this view.

Dr J Gwyn Jones was supported by the Welsh Scheme for the Development of Health and Social Research.

We wish to thank the physicians and surgeons of the University Hospital of Wales and Llandough Hospital, Penarth for allowing us to study their patients.

\section{Refereaces}

' Mols G. Recherches cytologiques et experimentales sur les cellules de Paneth. Arch Biol (Paris) 1930;40:111-50.
${ }^{2}$ Malanin GI. Direct quantitative eatimation of Paneth and total cell populations in the jejunal glands of Lieberkahn. Am J Anat 1975;142:201-4.

3 Gibbs NM. Incidence and significance of argentafiin and Paneth cells in some tumours of the large intestine. J Clin Pathol 1967;20:826-31.

4 Elmes ME. The Paneth cell population of the small intestine of the rat. J Pathol 1976:118:183-91.

${ }^{5}$ Hertzog AJ. The Paneth cell. Am J Pathol 1937;13:351-60.

- Lewin K. The Paneth cell in disease. Gut 1969;10:804-811.

7 Scott H, Brandtzaeg P. Enumeration of Paneth cells in coeliac disease. Gut 1981;22:812-6.

- Rodning CB, Erlandsen SL, Dodd Wilson I, Carpenter AM. Light microscopic morphometric analysis of rat ileal mucosa. II Component quantitation of Paneth cells. Anat Rec 1982;204:33-8.

- Sandow MJ, Whitehead R. The Paneth cell. Gut 1979;20:42031

10 Coyne MB. Quntitative image analyser using a colour television display for medical applications. Medical Biological Engineering 1974;12:295-302.

" Stanton MR, Garrahan NJ. The use of a simple light-pen system with a colour television image analyser. Medical Biological Engineering 1975;13:311-4.

${ }^{12}$ Erlandsen SL, Parsons JA, Taylor TD. Ultrastructural immunocytochemical localisation of lysozyme in the Paneth cells of man. $J$ Histochem Cytochem 1974;22:401-13.

${ }^{13}$ Elmes ME, Love AHG. Paneth cells and the intestinal microflora. Proceedings European Society for Clinical Investigation, 9th Meeting. Abstract No. 191, 1975.

${ }^{14}$ Enander LK, Nilson R, Ryden AC, Schwan A. The aerobic and anaerobic microflora of the gastric remnant more than $\mathbf{1 5}$ years after Billroth II resection. Scand $J$ Gastroenterol 1982;17:715-20.

Requests for reprints to: Dr Margaret E Elmes, Department of Pathology, University Hospital of Wales, Heath Park, Cardiff CF4 4XN, Wales. 